\title{
Modification of Dietary Habits for Prevention of Gout in Japanese People: Gout and Diet
}

\author{
Takashi Koguchi \\ Department of Human Education, Kokugakuin Tochigi Junior College, Tochigi, Japan
}

Email address:

echo130@nifty.com

\section{To cite this article:}

Takashi Koguchi. Modification of Dietary Habits for Prevention of Gout in Japanese People: Gout and Diet. American Journal of Health Research. Vol. 9, No. 5, 2021, pp. 176-189. doi: 10.11648/j.ajhr.20210905.16

Received: August 1, 2021; Accepted: September 1, 2021; Published: September 10, 2021

\begin{abstract}
The prevalence of gout in Japan has increased markedly since the 1960s. This phenomenon is thought to be attributed to the westernization of the Japanese diet since 1955. The objective of this article is to propose a preventive method for gout through the evaluation of recent dietary habits in Japanese people. In this article, the author suggests what foods should be chosen in proper diet or dietary pattern in Japanese people referencing the results of clinical research reported. Furthermore, this article suggests essentials of behavior for prevention of gout and its comorbidities. Diet and dietary pattern for the prevention of gout in Japanese people (especially adults) are suggested as follows: avoidance of purine-rich diet, uric acid-prone dietary pattern, animal foods dietary pattern, and the Western diet; encourage high fruit and soybean products diet, less protein-rich and more vegetable/fruit-rich materials diet, soybean products and fruit dietary pattern, polyphenol-rich dietary pattern, higher adherence to the Mediterranean diet (the traditional Mediterranean diet) and its dietary pattern, higher adherence to the Dietary Approaches to Stop Hypertension (DASH) diet and its dietary pattern, and vegetarian diet (plant-based diet). Referring to or adopting dietary patterns such as the Mediterranean diet, the DASH diet, and vegetarian diet (plant-based diet), the author wishes to emphasize that Japanese people should eat a diet in which consciously selects foods rich in dietary fiber, vitamin A, vitamin $B_{1}$, vitamin $B_{2}$, vitamin $\mathrm{B}_{6}$, calcium, potassium, magnesium, and zinc and decreases intakes of fat (especially animal fat) and salt. Modification of behavior (diet, alcohol, body weight, physical activity, and tobacco) for the prevention of gout and its comorbidities in Japanese adult people is suggested as follows: avoidance of the Western diet and its dietary pattern; encourage higher adherence to the Mediterranean diet (the traditional Mediterranean diet) and its dietary pattern, higher adherence to the DASH diet and its dietary pattern, and vegetarian diet (plant-based diet); limiting alcohol consumption; weight management including proper calorie intake; weight loss for overweight and obese people; adequate physical exercise (e.g., moderate intensity aerobic exercise for 30 minutes on 5-7 days per week, vigorous intensity aerobic physical activity for 75 minutes per week); and smoking cessation. The above behavior for the prevention of gout may also play a helpful role in the prevention of gout and its comorbidities.
\end{abstract}

Keywords: Comorbidities of Gout, Dietary Habits, Gout, Hyperuricemia, The Mediterranean Diet, The DASH Diet, Uric Acid

\section{Introduction}

The global burden of gout is substantial and seems to have been increasing in many parts of the world including Japan over the past 50 years [1-4]. A high serum uric acid (SUA) concentration (hyperuricemia) is frequently associated with gout [5]. The Japanese Society of Gout and Uric \& Nucleic Acids [6] has stated that hyperuricemia is a risk factor for gout (as uratosis). In the US National Health and Nutrition Examination Survey (NHANES) 2007-2008, the comorbidities of individuals with hyperuricemia, gout, or both hyperuricemia and gout were hypertension, chronic kidney disease (CKD), obesity (body mass index: BMI $\geq 30 \mathrm{~kg} / \mathrm{m}^{2}$ ), diabetes mellitus, nephrolithiasis, and cardiovascular disease (CVD) (myocardial infarction, heart failure, stroke), though the prevalence of the comorbidities of gout are different from those of hyperuricemia or both hyperuricemia and gout [7]. Considering that gout often coexists with other important diseases, the author wishes to emphasize the importance of dietary habits for decreasing SUA concentrations to prevent 
gout. It is also important to maintain SUA concentration within the normal physiological range in order to exert the beneficial effects of the antioxidant properties of uric acid (UA), such as its neuroprotective action [8] and prevention of bone loss and osteoporosis [9].

In the articles in this series reported by Koguchi [10-12], modification of dietary habits for the prevention of gout in Japanese people (especially adults) is suggested as follows: avoidance of excessive intake of saturated fatty acids and cholesterol; replacement of saturated fatty acids with monoand polyunsaturated ones (especially n-3 polyunsaturated fatty acids); limiting the intake of meat, organ meats high in purine content (e.g., liver, kidney), confectioneries (sugary foods including desserts and sweets), and sugar-sweetened beverages; limiting or decreasing intake of fat (especially animal fat), salt, oils and fats, and seasonings and condiments (soy paste, soy sauce, and sauce); limiting alcohol and alcoholic beverage consumption; encourage intake of fiber-rich foods (e.g., cereals, whole grains, high-fiber bread), eggs, milk and dairy products (especially low-fat dairy products), legumes, seeds and nuts, fruit, vegetables, and coffee; increase intake of foods rich in dietary fiber, vitamin $\mathrm{A}$, vitamin $B_{1}$, vitamin $B_{2}$, vitamin $B_{6}$, calcium, potassium, magnesium, and zinc; and maintenance of good hydration.

Diets that lower SUA concentration and decrease hyperuricemia risk may have a beneficial effect on the prevention of gout. In this article, the author introduces clinical research reports that reveal association between diet or dietary pattern and SUA concentrations or hyperuricemia risk (Table 1) and suggests what foods should be chosen in proper diet or dietary pattern in Japanese people referencing the results of clinical research reported. Furthermore, this article suggests essentials of behavior for prevention of gout and its comorbidities.

Table 1. Association between food intake with plasma or serum uric acid concentrations, hyperuricemia risk, and gout risk in individuals with or without hyperuricemia or gout in clinical research.

\begin{tabular}{|c|c|c|c|}
\hline Diet or Dietary Pattern & PUA or SUA & Hyperuricemia risk & Gout risk \\
\hline High-protein diet & $\downarrow *[13-17]$ & & \\
\hline Purine-free diet & $\downarrow[20]$ & & \\
\hline Purine-rich diet & $\uparrow[27-33]$ & & \\
\hline High fruit and soybean products diet & $\downarrow[44]$ & & \\
\hline Less protein-rich and more vegetable/fruit-rich materials diet & $\downarrow[45,46]$ & & \\
\hline $\begin{array}{l}\text { Calorie restricted diet composed of } 40 \% \text { carbohydrate including whole grains, } 30 \% \text { protein, } \\
\text { and } 30 \% \text { fat }\end{array}$ & $\downarrow[47]$ & & \\
\hline A dietary urate index dietary pattern & $\uparrow[48]$ & & \\
\hline Uric acid-prone dietary pattern & $\uparrow[49]$ & & \\
\hline Soybean products and fruit dietary pattern & & $\downarrow[50]$ & \\
\hline Animal foods dietary pattern & & $\uparrow[51]$ & \\
\hline The Western diet & & & $\uparrow[1,52]$ \\
\hline The Western dietary pattern & & $\leftrightarrow[50]$ & \\
\hline The Mediterranean diet & $\downarrow[83,110]$ & & \\
\hline Higher adherence to the Mediterranean diet & $\downarrow[84-86]$ & $\downarrow[81,84,85]$ & \\
\hline The DASH diet & $\downarrow[118]$ & & \\
\hline Higher adherence to the DASH diet & & & $\downarrow[52]$ \\
\hline Vegetarian diet & & & $\downarrow[133]$ \\
\hline
\end{tabular}

${ }^{*} \uparrow$, Increase; $\downarrow$, Decrease; $\leftrightarrow$, No influence on risk. Abbreviation: The DASH diet, The Dietary Approaches to Stop Hypertension diet; PUA, plasma uric acid; SUA, serum uric acid.

\section{Effect of Diet on Plasma or Serum Uric Acid Concentrations}

\subsection{High-protein Diet}

High-protein diet was associated with increased urinary uric acid (UUA) excretion and lowered serum uric acid (SUA) levels [13-17]. High in vegetable protein (specifically, wheat gluten) protein diet ( $27 \%$ of total energy from protein) lowered SUA concentrations in hyperlipidemia in a randomized, crossover trial [18]. Higher intake of total protein was associated with increased gout risk in a prospective study [19].

\subsection{Purine-free Diet}

An observational study found that a strict purine-free diet reduced serum uric acid (SUA) level by $15-20 \%$ [20]. Some of these restrictions can lead to reduction of life quality. Many researchers [21-24] have announced that traditional low purine diets are generally unpalatable and nutritionally poor, and they are not usually recommended. Fam [21] and Schlesinger [25] have also stated that a rigid purine-free diet can rarely be sustained for a long period of time.

\subsection{Purine-rich Diet}

Purine-rich foods include animal meat (i.e., beef, pork, lamb, organ meats, and meat extracts), seafood (i.e., fish fillets, tuna, shrimp, lobster, clams, etc.), plants (i.e., yeast extracts, peas, beans, lentils, asparaguses, cauliflowers, spinach, mushrooms, bamboo shoots), seaweed (e.g., nori, wakame), seasonings (i.e., soup stock, oyster sauce, consommé, Chinese soup, etc.) $[6,26]$. By contrast, dairy products (i.e., milk, cheese, yogurt, ice cream), grains and their products (i.e., bread, pasta, cereals), nuts, fruit, vegetables, sugars and sweets, sugar-sweetened beverages, and alcoholic beverages are low in purine $[6,26]$. Eggs and milk contained no purine 
$[6,26]$. The amounts of purines in distilled liquor (i.e., whiskey, brandy, shochu, awamori) and plum wine do not almost contain $(0-0.4 \mathrm{mg} / 100 \mathrm{~mL})$ and those in beer and wine were $3.3-9.8 \mathrm{mg} / 100 \mathrm{~mL}$ and $0.4-1.6 \mathrm{mg} / 100 \mathrm{~mL}$, respectively $[6,26]$. The Ministry of Health, Labour and Welfare in Japan have not been investigated the daily intake of purines in Japanese people yet.

Purine, such as ribonucleic acid (RNA), adenosine-5' -monophosphate guanosine-5'-monophosphate (5'-AMP), (5'-GMP), inosine-5'-monophosphate (5'-IMP), hypoxanthine, and adenine, increased plasma uric acid (PUA) or serum uric acid (SUA) concentrations [27-33]. Schlesinger [25] stated that the variation in hyperuricemia and gout with different purine-rich foods may be explained by the variation in the amounts and types of purine content and their bioavailability for purine-to-uric acid metabolism. Bowering et al. [29] found that daily administration of $4 \mathrm{~g}$ of RNA to healthy subjects doubled the uric acid (UA) pool, increasing serum uric acid (SUA) concentration, and increasing urinary uric acid (UUA) excretion, which cause overproduction-type hyperuricemia. Brulé et al. [34], Yokozawa et al. [35, 36], and Koguchi et al. [37] reported that dietary adenine caused experimental underexcretion-type hyperuricemia through renal dysfunction in rats, which seems to be due to the 2,8-dihydroxyadenine nephrolithiasis. Considering the maximum recommended amount of nucleic acid from the daily diet, long-term excessive intake of adenine-rich foods which is containing 50 $\mathrm{mg}$ or more adenine in $100 \mathrm{~g}$ of food [e.g., animal liver, legumes (soybeans, peas, lentils, white beans, green beans, red beans, etc.) $[6,26]]$ can cause elevated SUA levels due to decreased kidney function. It is necessary to limit the amount of one serving of purine-rich foods, especially adenine.

Havlik et al. [38] found that protein-rich vegetable-based meat substitutes are more suitable for dietary considerations in a low-purine diet for subjects with hyperuricemia.

In a case-crossover study, there was a dose-response relationship between increasing purine intake and risk of gout flares and the impact of plant purine on gout attacks was substantially smaller than purine from animal sources in gout patients [39].

The guidelines for the management of gout have stated the following view for purine intake in patients of gout: (1) limit purine intake [40]; (2) avoidance of purine intake [6]; (3) a daily intake of purine should be less than 400mg [6]; (4) recommendation for a purine-low diet [41]; and (5) encourage diets rich in plant foods inclusion of soybeans and vegetable sources of protein, but high-purine foods at the same time avoid [42]. Japanese Urological Association., Japanese Society of Endourology., Japanese Society on Urolithiasis Research [43] has recommended refraining from overdose of purines for patients with urolithiasis.

\subsection{High Fruit and Soybean Products Diet}

In an open randomized controlled trial, Zhang et al. [44] found that the standard diet (dietary guidelines for hyperuricemia) and high fruit and soybean products diet decreased serum uric acid (SUA) concentrations in Chinese asymptomatic hyperuricemia adults. They [44] stated that high fruit and soybean products dietary intervention could be an effective alternative to a standard diet for achieving clinically important reductions in SUA concentrations for asymptomatic hyperuricemia adults.

\subsection{Less Protein-rich and More Vegetable/Fruit-rich Materials Diet}

In a clinical trial, Kanbara et al. [45, 46] reported that the less protein-rich and more vegetable/fruit-rich materials diet significantly decreased serum uric acid (SUA) concentrations and significantly increased urinary uric acid (UUA) excretion and uric acid (UA) clearance, compared with the protein-rich and less vegetable/fruit materials diet. These reports suggest that urine alkalization by eating less protein-rich and more vegetable/fruits-rich materials diet is important and effective for promoting UA excretion $[45,46]$.

\subsection{Calorie Restricted Diet Composed of 40\% Carbohydrate Including Whole Grains, 30\% Protein, and 30\% Fat}

In an observational study performed by Dessein et al. [47], thirteen non-diabetic men with gout (median age 50, range 38-62) ingested calorie restricted diet (1,600 kcal a day) composed of $40 \%$ carbohydrate [replacement of refined carbohydrates (e.g., white flour, white rice) with complex ones (e.g., whole wheat flour, brown rice)], 30\% protein, and $30 \%$ fat [replacement of saturated fats (e.g., dairy fats, meat fat) with mono- and polyunsaturated fats (e.g., macadamia nuts, almonds, peanuts and peanut butter, olive oil, canola oil, avocados)] for 16 weeks. The mean serum uric acid (SUA) concentration decreased by $18 \%$ in gouty patients after four months of dietary intervention. This was accompanied by a $67 \%$ reduction in monthly gouty attack frequency. This pilot study also reduced weight and had beneficial effects on dyslipidemia in gout. Dessein et al. [47] have stated that weight reduction associated with a change in proportional macronutrient intake is beneficial, reducing the SUA levels and dyslipidemia in gout.

\section{Effect of Dietary Pattern on Plasma or Serum Uric Acid Concentrations and Hyperuricemia}

\subsection{A dietary Urate Index Dietary Pattern}

In a large prospective cohort study, a dietary urate index was positively associated with serum uric acid (SUA) concentrations in the total population (Whites and African Americans) [48]. A dietary urate index was as follows: (1) added sugars (teaspoons/d or approximately $4.2 \mathrm{~g} /$ day); (2) alcoholic beverages (drinks/d, with one drink defined as $12 \mathrm{fl}$ oz of beer, $5 \mathrm{fl} \mathrm{oz}$ of wine or $1.5 \mathrm{fl} \mathrm{oz}$ of eighty-proof distilled spirits; $1 \mathrm{~g}=$ approximately $0.03 \mathrm{fl} \mathrm{oz}$ ); (3) ounce equivalents/d of red meats $(1 \mathrm{oz}=28.3 \mathrm{~g})$; (4) ounce equivalents/d of fish (sum of fish high and low in n-3 fatty 
acids); (5) cup equivalents/d of legumes; (6) cup equivalents/d of dairy products (milk, cheese and yogurt); (7) dietary vitamin $\mathrm{C}$ from foods in $\mathrm{mg} /$ day; and (8) caffeine from all sources (g/day) [48].

\subsection{Uric Acid-prone Dietary Pattern}

In a cross-sectional study of 266 ethnic Chinese adults in Taiwan, there was a positive association between the "uric acid-prone (composes of meat, seafood, organ meat, eggs and beverages)" dietary pattern and plasma uric acid (PUA) concentrations after adjusted for age, gender and body mass index (BMI) [49].

\subsection{Soybean Products and Fruit Dietary Pattern}

In a case-control study in Chinese adults, there was a negative association between the "soybean products and fruit (high in soybean products, fruit, vegetables and starchy tubers)" dietary pattern and the risk of asymptomatic hyperuricemia [serum uric acid (SUA) level $>7.0 \mathrm{mg} / \mathrm{dL}$ $(416.4 \mu \mathrm{mol} / \mathrm{L})$ among men and $>6.0 \mathrm{mg} / \mathrm{dL}(356.9 \mu \mathrm{mol} / \mathrm{L})$ among women], independent of blood lipids [50].

\subsection{Animal Foods Dietary Pattern}

In a case-control study in Chinese adults, there was a positive association between the "animal products and fried food (high in pork, eggs, animal giblets, poultry and fried wheat products while low in fruit and vegetables)" dietary pattern and the risk of asymptomatic hyperuricemia [serum uric acid (SUA) level $>7.0 \mathrm{mg} / \mathrm{dL}(416.4 \mu \mathrm{mol} / \mathrm{L})$ among men and $>6.0 \mathrm{mg} / \mathrm{dL}(356.9 \mu \mathrm{mol} / \mathrm{L})$ among women] [50]. In a case-control study, the animal foods dietary pattern characterized by higher intake of an animal organ, seafood and processed meat products was associated with higher prevalence of newly diagnosed hyperuricemia in a Chinese population [51].

\section{Effect of Diet and Dietary Pattern on Plasma or Serum Uric Acid Concentrations, Hyperuricemia, and Gout}

\subsection{The Western Diet}

\subsubsection{The Western Diet}

The Western diet is characterized by high intake of red and processed meats, animal fat, beverages sweetened with sugar, sweets, desserts, French fries, and refined grains contains many foods and low intake of fresh fruit and vegetables and low-fat dairy products $[1,52,53]$. The Western diet was associated with low fiber intake, which is often accompanied by elevated levels of inflammatory biomarkers such as serum $\mathrm{C}$-reactive protein, tumor necrosis factor-alpha (TNF- $\alpha$ ), and interleukin-6 (IL-6) [54-56]. The Western diet was associated with increased risk of gout $[1,52]$ and chronic kidney disease (CKD) [53, 57].

\subsubsection{The Western Dietary Pattern}

The "Western (high in beef, lamb, cake, and beverages including juice and alcoholic beverages)" dietary pattern was not associated with the risk of asymptomatic hyperuricemia in a case-control study in China [50]. Increased intake of fried foods was associated with increased hyperuricemia risk [58].

The Western dietary pattern was associated with increased risk of rapid estimated glomerular filtration rate (eGFR) decline of $\geq 3 \mathrm{~mL} / \mathrm{min} / 1.73 \mathrm{~m}^{2}$ per year [59], type 2 diabetes mellitus [60] and coronary heart disease (CHD) [61].

\subsection{Polyphenol-rich Dietary Pattern}

Plant foods contain polyphenols [62]. Polyphenols such as procyanidins from grape seeds [63], quercetin [64-66], myricetin [64, 65], kaempferol [64], puerarin [64], chlorogenic acid [67], apigenin [68], luteolin [66, 68], genistein [65], theaflavin [69], and tea catechins [e.g., catechin, epicatechin, (-)-epigallocatechin, (-)-epicatechin-3-gallate, (-)-epigallocatechin-3-gallate] [70] inhibit xanthine oxidase activity, thus suppressing uric acid (UA) production. In a randomized, double-blinded, placebo-controlled, crossover trial, quercetin significantly reduced plasma uric acid (PUA) concentration (approximately $8 \%$ ) compared with baseline (before ingestion of quercetin) [71]. The consumption of isoflavones was inversely associated with the presence of hyperuricemia in women [72].

The foods that high in the above polyphenols $(>3.0 \mathrm{mg} / 100$ $\mathrm{g} \mathrm{FW}$ or $>3.0 \mathrm{mg} / 100 \mathrm{~mL}$ ) are alcoholic beverages (rose wine, red wine), beverages (apple pure juice, coffee beverage, rowanberry pure juice, chocolate milk, plum pure juice, apple pure juice, fox grape pure juice, pear pure juice), cocoa (chocolates, cocoa powders), herbs (common sage, common thyme, lemon verbenas, Italian oreganos, marjoram, Mexican oreganos, rosemaries), fruit (blackberries, black currants, black elderberries, European cranberries, apricots, grapes, fox grapes, nectarines, peaches, plums, red raspberries, sour cherries, strawberries, sweet cherries, quinces, loquats, apples, pears, custard apples), nuts (almonds, hazelnuts, pecan nuts, pistachio nuts), legumes (common beans, broad bean seeds, soybeans), soy products (soy paste, soy bacon, soy flour, soy meat, soy tempe, soy tofu), spices (capers, caraways, cloves, cumin), vegetables (black olives, broad bean pods, broccoli, globe artichokes), tea infusions (black tea infusion, green tea infusion, oolong tea infusion), herb infusions (peppermint tea) [73]. Dietary polyphenol intake in the US was $\sim 1 \mathrm{~g}$ /day [74]. The Ministry of Health, Labour and Welfare in Japan have not been investigated the daily intake of polyphenols in Japanese people yet. Since it has reported that excessive intake of some polyphenols resulted in growth depression in animals [75], it must take care of excessive intake of polyphenols.

Dietary polyphenols and polyphenol-rich foods exert antioxidant effect [76] and anti-inflammatory effects [76-78].

A polyphenol-rich dietary pattern, such as the Mediterranean diet, is likely to play a role in its anti-inflammatory effect and downregulation of cellular and circulating inflammatory biomarkers related to atherosclerosis in subjects at high risk of cardiovascular disease (CVD), as 
reviewed in detail by Ríos-Hoyo et al. [76], Mena et al. [79], and Medina-Remón et al. [80]. also suggest that high polyphenol intake improves cardiovascular risk factorsmainly systolic and diastolic blood pressure and the lipid profile.

\subsection{The Mediterranean Diet}

\subsubsection{Higher Adherence to the Mediterranean Diet (The Traditional Mediterranean Diet)}

The traditional Mediterranean diet is characterized by a high intake of fruit, vegetables, legumes, olive oil, nuts, and whole grain; moderate consumption of wine, dairy products, and poultry; and a low consumption of red meat, sweet beverages, creams, and pastries [81].

Plasma uric acid (PUA) concentration on the consumption of the vegetable-soup "gazpacho" (500 mL/day) for 14 days was significantly lower than that at baseline (before drinking the soup) in healthy men [82].

In an intervention study in patients with hyperuricemia [Mean serum uric acid (SUA) concentration: $9.12 \mathrm{mg} / \mathrm{dL}$ $(542.46 \mu \mathrm{mol} / \mathrm{L})]$ for 6 months, the Mediterranean diet provoked a $20 \%$ reduction in serum uric acid (SUA) concentration [Mean SUA concentration $6.92 \mathrm{mg} / \mathrm{dL}$ (411.6 $\mu \mathrm{mol} / \mathrm{L})]$ after the first month and SUA concentrations remained constant for five months [Mean SUA concentration 6.1-6.4 $\mathrm{mg} / \mathrm{dL}(362.8-380.7 \mu \mathrm{mol} / \mathrm{L})]$ in patients with hyperuricemia [Mean SUA concentration $9.12 \mathrm{mg} / \mathrm{dL}(542.5$ $\mu \mathrm{mol} / \mathrm{L})]$ [83].

Higher adherence to the Mediterranean diet was associated with decreased SUA concentrations [84-86] and a lower likelihood of hyperuricemia $[84,85]$. In the PREDIMED trial, a greater baseline adherence to the Mediterranean diet was associated with a lower risk of hyperuricemia in elderly Mediterranean participants at high cardiovascular risk [81]. However, the effects of the Mediterranean diet on patients with gout or hyperuricemia have not yet been studied sufficiently. There is a needed for more studies in gout to see if the Mediterranean diet may prevent gout or reduce gouty attacks.

The Mediterranean diet has antioxidant [87] and anti-inflammatory properties [88]. Decrease in serum C-reactive protein levels have been also observed in the Mediterranean diet with olive oil [79, 88]. The Mediterranean diet with olive oil reduced plasma C-reactive protein level by $0.54 \mathrm{mg} / \mathrm{L}$ compared with a low-fat diet [88]. An energy-unrestricted Mediterranean diet, supplemented with extra-virgin olive oil or nuts, had a lower rate of major cardiovascular events compared to a reduced-fat diet [89]. In an intervention study, eating the Mediterranean diet for 3 months improved rheumatoid arthritis [90].

Higher adherence to the Mediterranean diet was significantly associated with lower levels of lipid biomarkers (LDL-cholesterol and apo B) [86], renal function indicators (creatinine and uric acid) [86], systolic blood pressure [91] and diastolic blood pressure [86, 91], and hepatic function biomarkers (serum $\gamma$-glutamyl-transpeptidase and glutamate-pyruvate transaminase) [86].
Greater adherence to the Mediterranean diet was associated with decreased risk of renal function [92], chronic kidney disease (CKD) [93, 94], obesity [95], cardiovascular disease (CVD) [96-100], cancer [76, 101], Parkinson's disease [101], Alzheimer's disease [101], dementia and dementia progression [102], noncontrolled asthma [103], and renal-cause mortality [92].

Higher adherence to the alternate Mediterranean diet was significantly associated with decreased risk of type 2 diabetes mellitus [104], all-cause mortality [105], CVD-cause mortality [105], and cancer mortality [105].

In the National Kidney Foundation's Kidney Disease Outcomes Quality Initiative (KDOQI) clinical practice guideline for nutrition in CKD (CKD stages 1-5D, nondialysis, maintenance hemodialysis, peritoneal dialysis, posttransplantation, transplant) [106], the Mediterranean diet improves lipid profiles in adults with CKD 1-5 not on dialysis or posttransplantation with or without dyslipidemia to CKD. The Mediterranean diet is encouraged for the prevention and/or management of type 2 diabetes mellitus [107, 108].

\subsubsection{The Mediterranean Dietary Pattern}

The Mediterranean dietary pattern has health benefits. The Mediterranean dietary pattern can be characterized by the following four essential dietary indicators: (1) Monounsaturated to saturated fatty acid ratio (range: 1.6 to 2.0); (2) Intake of dietary fiber (41 to $62 \mathrm{~g} /$ person/day); (3) Antioxidant capacity of the whole diet (3500 to 5300 trolox equivalent/person/day); and (4) Phytosterols intake (370 to $555 \mathrm{mg} /$ person/day) [109].

A systematic review reported by Vedder et al. [110] concluded that diet interventions, including low-calorie diet (but not fasting), purine-low diets, and different variations of the Mediterranean diet, were able to decrease serum uric acid (SUA) concentrations in patients with asymptomatic hyperuricemia or gout. The range in SUA change after the above-mentioned interventions (excluding fasting) was +0.3 to $-2.9 \mathrm{mg} / \mathrm{dL}$ [110]. According to the EULAR guideline, this implicates a required decrease of 0.5 to $3.7 \mathrm{mg} / \mathrm{dL}$ to achieve target levels [41].

The Mediterranean dietary pattern reduced weight gain $[110,111]$ and improved lipid profiles [110]. The Mediterranean dietary pattern was associated with decreased risk of overweight or obesity [112], all-cause mortality [113], and cancer-cause mortality [113].

\subsection{The Dietary Approaches to Stop Hypertension (DASH) Diet}

\subsubsection{Higher Adherence to the Dietary Approaches to Stop Hypertension (DASH) Diet}

The Dietary Approaches to Stop Hypertension (DASH) diet emphasizes high intake of fruit, vegetables, nuts and legumes, low fat dairy foods, and whole grains; low intake of sodium, sweets including sweetened beverages, red meat, processed meat, saturated fats, and total fats [114-116]. The composition of macronutrient and mineral of the DASH diet are as follows: total fat, $27 \%$ of calories; saturated fat, $6 \%$ of calories; 
cholesterol, $150 \mathrm{mg}$; protein, $18 \%$ of calories; carbohydrate, $55 \%$ of calories; fiber, $30 \mathrm{~g}$; sodium, $2,300 \mathrm{mg}$; potassium, 4,700 mg; calcium, 1,250 mg; magnesium, $500 \mathrm{mg}$ [116, 117].

In a randomized, crossover feeding trial in 103 adults with prehypertension or stage 1 hypertension, the DASH diet reduced serum uric acid (SUA) concentration compared with the control diet $(-0.35 \mathrm{mg} / \mathrm{dL}[95 \%$ confidence interval (95\%CI [-0.65, -0.05], $\mathrm{P}=0.02)$, and this effect was greater among participants with hyperuricemia $(-1.29 \mathrm{mg} / \mathrm{dL}[95 \% \mathrm{CI}$ $-2.50,-0.08]$ ] [118]. In the DASH diet groups, medium sodium intake (a target of $120 \mathrm{mmoles} /$ day) and high sodium intake (a target of $180 \mathrm{mmoles} /$ day) lowered SUA concentrations compared to low sodium intake (a target of 60 mmoles/day), respectively [118]. In case of the DASH diet, $2,300 \mathrm{mg}$ of sodium intake per day in adults with prehypertension or stage 1 hypertension seems to be appropriate.

In a randomized trial of African Americans with controlled hypertension from an urban clinic, partial replacement of diet with DASH foods lowered SUA concentrations compared with higher baseline SUA concentrations (SUA concentration $>$ $8 \mathrm{mg} / \mathrm{dL}$ ) [119]. Baseline changes in SUA concentrations were inversely associated with changes in systolic blood pressure, diastolic blood pressure, and urine sodium excretion in African Americans with controlled hypertension from an urban clinic [119]. In a randomized-controlled trial, 103 pre-hypertensive or hypertensive adults (SUA concentration $\geq$ $6 \mathrm{mg} / \mathrm{dL}$ ), for 90 days, the DASH diet lowered SUA concentrations compared to the typical American diet at 90 days [120].

Higher adherence to the DASH diet was associated with decreased risk of gout [52], kidney disease [121], overweight/obesity [116], type 2 diabetes mellitus [103, 116, 122], chronic heart disease [123], coronary heart disease (CHD) [123], stroke [123], kidney stones [124], rapid estimated glomerular filtration rate (eGFR) decline [59], dementia and dementia progression [125], all-cause mortality [105, 125], renal-cause mortality [92], CVD-cause mortality [105, 125], stroke-cause mortality [125], and cancer-cause mortality [105, 125]. Higher adherence to the DASH diet improved renal function by $15 \%$ compared to lower adherence [92].

Higher adherence to the DASH diet was inversely associated with waist circumference and diastolic blood pressure [86]. A meta-analysis showed that the DASH diet reduced systolic blood pressure and diastolic blood pressure $[126,127]$. In a randomized controlled outpatient feeding trial, the DASH diet has shown a reduction of total, LDL-, and HDL-cholesterol concentrations [128].

The guidelines have encouraged the DASH diet for patients with type 2 diabetes mellitus [107] and hypertension [129]. The National Kidney Foundation-Kidney Disease Outcomes Quality Initiative Guidelines on Hypertension and Antihypertensive Agents in CKD recommended a modified version of the DASH diet (protein intake: 0.6-0.8 g/ $\mathrm{kg} / \mathrm{day}$; phosphorus intake: $0.8-1.0 \mathrm{~g} /$ day; potassium intake: $2-4 \mathrm{~g} /$ day) for persons with CKD stages 3 and 4 (eGFR between 15 and $59 \mathrm{~mL} / \mathrm{min} / 1.73 \mathrm{~m}^{2}$ ) [130].

\subsubsection{The Dietary Approaches to Stop Hypertension (DASH) Dietary Pattern}

The DASH dietary pattern, which is a diet rich in fruit, vegetables, nuts and legumes, low-fat dairy products and whole grains, and with low intake of sodium, sugar-sweetened beverages, and red and processed meats, was associated with a lower risk of gout, suggesting that its effect of lowering serum uric acid (SUA) levels in individuals with hyperuricemia translates to a lower risk of gout [52].

\subsection{Vegetarian Diet (Plant-based Diet)}

Vegetarians avoid purine-rich meat and seafood, while consuming more vegetables, whole grains, seeds and nuts $[131,132]$.

In two separate prospective cohort studies from the Tzu Chi population (Taiwanese), a vegetarian diet (vs a nonvegetarian diet) was associated with a lower risk of gout [133]. Taiwanese vegetarians had a lower intake of dairy, eggs, coffee, tea, sugar sweetened beverages, and higher intakes of soybeans, fruit, vegetables, dietary fiber, vitamin $\mathrm{C}$, and avoiding meat and fish, compared with Taiwanese nonvegetarians [133].

Fruit, vegetables, and various herbs consist of many phytochemicals, and other micronutrient compounds that have been shown to inhibit uric acid (UA) synthesis [134], including olive leaf constituents [68], certain Indian medicinal plants [135], DKB114, which is a mixture of Chrysanthemum Indicum Linne flower and Cinnamomum Cassia (L.) J. Presl Bark extracts [136] inhibit xanthine oxidase activity, thus suppressing uric acid (UA) production. A Chinese herbal decoction (Diclofenac Sodium Enteric-coated Tablets or Meloxicam Tablets) decreased serum uric acid (SUA) levels in gout patients [137]. Phytochemicals, which are found in fruit, vegetables, grains, beans, and other plants, may attenuate the nucleotide-binding and oligomerization domain-like receptor, leucine-rich repeat and pyrin domain-containing 3 (NLRP3) pathway [138, 139]. Since vegetarian diets tend to contain lower saturated fat, higher unsaturated fat and phytochemical-rich plant foods [131, 132], vegetarian diets may prevent inflammatory responses that trigger gout attacks by dampening the activation of nucleotide-binding and oligomerization domain-like receptor, leucine-rich repeat and pyrin domain-containing 3 (NLRP3) inflammasome [138, 140].

The risk of UA crystallization was highest during the ingestion of the self-selected meat diet and the Western-type diet, but the ingestion of the vegetarian diet led to a significant reduction in the risk of UA crystallization by $93 \%$ compared to the Western-type diet [141].

Vegetarian diets have been shown to lower blood pressures in a meta-analysis of randomized, controlled trials (systolic blood pressure (SBP): $-4.8 \mathrm{mmHg}$ and diastolic blood pressure (DBP): $-2.2 \mathrm{mmHg}$ ) [142] and in a prospective cohort study (odds ratio: 0.66, 95\% CI: 0.50, 0.87) [143]. Vegetarian diets have been shown to reduce gout- associated comorbidities, such as hypertension [142, 143], diabetes mellitus [144, 145], and cardiovascular diseases (CVD) [146]. 


\subsection{The Mediterranean Diet, the Dietary Approaches to Stop Hypertension (DASH) Diet, and Vegetarian Diet (Plant-based Diet)}

Both the Mediterranean diet and the DASH diet include a high intake of fruit, vegetables, whole-grain cereals, legumes and nuts, together with a moderate consumption of fish and low-fat dairy products, and low consumption of meat, meat products, and sweets and commercial pastries. Therefore, the Mediterranean diet and the DASH diet would be possible to play a role in the prevention of gout and its comorbidities including various lifestyle-related diseases. In the category of Mediterranean-style diet, the DASH diet is most probably best defined and evidence based regarding cardiovascular risk factors [110]. The DASH diet is a moderate form of a plant-rich diet and is described as being similar to "lacto-ovo vegetarian" diet [147]. The American Diabetes Association (ADA) [107] has encouraged the Mediterranean diet, the DASH diet, and plant-based diet for the management of type 2 diabetes and prediabetes.

\section{Essentials of Behavior for Prevention of Gout and Its Comorbidities}

\subsection{Modification of Behavior Except for Dietary Habits for Patients with Gout and Its Comorbidities in the Guidelines}

\subsubsection{Weight Management}

The guidelines have recommended weight loss for overweight and obese people with gout [5, 6, 40,41], or hypertension [129, 148-150] or diabetes mellitus [107, 108, $148,150]$ or cardiovascular diseases (CVD) [148, 150, 151].

\subsubsection{Physical Activity}

Physical activity for the management of patients with gout $[5,6,41]$, kidney stone (urolithiasis) [152], hypertension [129, $148,150]$, and diabetes mellitus [107, 148, 150, 153], and healthy adults for the prevention of cardiovascular diseases (CVD) $[148,150,151]$ is recommended in each guideline.

The guidelines have recommended vigorous intensity aerobic physical activity for patients with gout [6], hypertension [149], diabetes mellitus [107], and healthy adults for the prevention of CVD [148, 150] and moderate intensity aerobic exercise for patients with hypertension [129] and healthy adults for the prevention of CVD [148, 150, 151].

\subsubsection{Treatment of Tobacco Use}

Smoking cessation for the management of gout [5], chronic kidney disease (CKD) [154], hypertension [129], diabetes mellitus [107, 148], and for the prevention of cardiovascular diseases (CVD) [148, 150, 151] is recommended in each guideline.

\subsection{Essentials of Behavior for Prevention of Gout and Its Comorbidities}

The Western diet was associated with increased risk of gout, which may explain the increasing prevalence of gout in Western countries $[1,52]$. It seems that one of the factors contributing to the increase in the number of gout patients in Japan is due to the westernization of the diet, although gout is associated with environmental factors, such as dietary habits [155], alcohol consumption [155], aging [156], comorbidities [156], select lifestyle factors [156], physical function [157], and physical health-related quality of life [158, 159]. The Japanese Society of Gout and Uric \& Nucleic Acids [6] has stated that the increase in gout patients is attributed to changes in environmental factors rather than genetic background: they consider that environmental factors (e.g., purine intake, fructose intake, meat and visceral intake, alcohol consumption, strenuous muscle exercise, stress, obesity) and hyperuricemia is a risk factor for gout (as uratosis) [6]. Prevention of gout may involve behavior for the prevention and suppression of hyperuricemia from viewpoint of lowering SUA levels.

Modification of behavior (diet, alcohol, body weight, physical activity, and tobacco) for the prevention of gout in Japanese adult people is suggested as follows: avoidance of the Western diet and its dietary pattern; encourage higher adherence to the Mediterranean diet (the traditional Mediterranean diet) and its dietary pattern, higher adherence to the Dietary Approaches to Stop Hypertension (DASH) diet and its dietary pattern, and vegetarian diet (plant-based diet); limiting alcohol consumption; weight management including proper calorie intake; weight loss for overweight and obese people; adequate physical exercise (e.g., moderate intensity aerobic exercise for 30 minutes on 5-7 days per week, vigorous intensity aerobic physical activity for 75 minutes per week); and smoking cessation. The above behavior for the prevention of gout with proper choices of foods may also play a helpful role in the prevention of gout and its comorbidities.

\section{Conclusion}

The number of patients with gout has been increasing steadily in Japan [1-4]. Thus, the objective of this article was to propose a preventive method for gout through the evaluation of recent eating habits in Japan. Modification of dietary habits for the prevention of gout in Japanese people (especially adults) is suggested as follows: avoidance of excessive intake of saturated fatty acids and cholesterol; replacement of saturated fatty acids with mono- and polyunsaturated ones (especially n-3 polyunsaturated fatty acids); limiting the intake of meat, organ meats high in purine content (e.g., liver, kidney), confectioneries (sugary foods including desserts and sweets), and sugar-sweetened beverages; limiting or decreasing intake of fat (especially animal fat), salt, oils and fats, and seasonings and condiments (soy paste, soy sauce, and sauce); limiting alcohol and alcoholic beverage consumption; encourage intake of fiber-rich foods (e.g., cereals, whole grains, high-fiber bread), eggs, milk and dairy products (especially low-fat dairy products), legumes, seeds and nuts, fruit, vegetables, and coffee; increase intake of foods rich in dietary fiber, vitamin $\mathrm{A}$, vitamin $\mathrm{B}_{1}$, vitamin $\mathrm{B}_{2}$, vitamin $\mathrm{B}_{6}$, calcium, potassium, 
magnesium, and zinc; avoidance of purine-rich diet, uric acid-prone dietary pattern, animal foods dietary pattern, and the Western diet; encourage high fruit and soybean products diet, less protein-rich and more vegetable/fruit-rich materials diet, soybean products and fruit (high in soybean products, fruit, vegetables and starchy tubers) dietary pattern, polyphenol-rich dietary pattern, higher adherence to the Mediterranean diet (the traditional Mediterranean diet) and its dietary pattern, higher adherence to the Dietary Approaches to Stop Hypertension (DASH) diet and its dietary pattern, and vegetarian diet (plant-based diet); and maintenance of good hydration. From the results of several reports, Roman [156] has stated that weight loss, physical exercise, vitamin C supplementation, soy-containing products, low-fat milk, the DASH diet, and consumption of coffee and cherries have been linked to lowering serum uric acid (SUA) levels and a reduced incidence of acute gout attacks. The above modification of dietary habits for the prevention of gout in Japanese people may also play a helpful role in the prevention of cardiovascular disease (CVD). The American College of Cardiology and the American Heart Association [150], with respect to the prevention of CVD, have encouraged the intake of fruit, vegetables, legumes, nuts, whole grains, and fish, and have proposed minimizing the consumption of trans fats, added sugars (including sugar-sweetened beverages), red meats, sodium, and saturated fats. It is speculated that consuming these foods corresponds to the prevention of gout, but excessive intake of fish should be avoided. To properly choose and consume the following foods that contain the above-mentioned nutrients is important for Japanese people; that is to say, meat (poultry), seafood (salmon, sardines, tuna, trout, mackerel), seeds and nuts (pumpkin seeds, chia seeds, sunflower seeds, almonds, sesame seeds, pistachio nuts, hazelnuts, pecan nuts, walnuts, and pine nuts), grains (white rice, bread), whole grains (brown rice, fortified ready-to-eat cereals, oatmeal), potatoes, mushrooms (maitake mushrooms, shiitake mushrooms), legumes (common beans, kidney beans, soybeans, chickpeas, lentils), seaweed, fruit (apples, apricots, avocados, bananas, blackberries, black currants, black elderberries, cherries, European cranberries, kiwi fruits, oranges, raisins, red raspberries, strawberries), vegetables (black olives, broad bean pods, broccoli, garlic, globe artichokes, spinach, carrots, parsley, tomatoes, peppers, radishes, cucumbers, Chinese cabbages, pickles), soy products (soy milk, tofu, soy meat), dairy products (milk, cheese, yogurt), eggs, spices (capers, caraways, cloves, cumin), oils (olive oil), coffee and tea (black tea, green tea), and chocolates and cocoa powders $[160,161]$. Choosing and eating the above foods containing such nutrients and phytochemicals in the Mediterranean diet, the DASH diet, and vegetarian diet (plant-based diet) may also lead to prevent gout and its comorbidities [e.g., chronic kidney disease (CKD) [162], obesity [163], diabetes mellitus [108, 163], and CVD [163] caused by inflammation from elevated SUA concentrations. Referring to or adopting dietary patterns such as the Mediterranean diet, the DASH diet, and vegetarian diet (plant-based diet), the author wishes to emphasize that
Japanese people should eat a diet in which consciously selects foods rich in dietary fiber, vitamin $A$, vitamin $B_{1}$, vitamin $B_{2}$, vitamin $\mathrm{B}_{6}$, calcium, potassium, magnesium, and zinc and decreases intakes of fat (especially animal fat) and salt. Maintaining SUA concentrations within the normal physiological range that leads to the prevention of gout may exert the beneficial effects of the antioxidant properties of uric acid (UA).

\section{Conflict of Interest Statement}

The author declares that there are no conflicts of interest.

\section{Acknowledgements}

The author thanks Prof. Eiko Ota (Kokugakuin University Tochigi Junior College), Ms. Yuko Itabashi, Ms. Tamae Yanagita, Ms. Nao Uzuka, and Ms. Yumi Kuwabara for furnishing references at Kokugakuin University Tochigi Gakuen Library.

\section{References}

[1] Kuo, C. F., Grainge, M. J., Zhang, W., \& Doherty, M. (2015) Global epidemiology of gout: prevalence, incidence and risk factors. Nat Rev Rheumatol, 11, 649-662.

[2] Mikanagi, K. (1963) Gout in Japan. The Kyosai Medical Journal, 12, 14-37 (in Japanese).

[3] Nishioka, K., Mikanagi, K., \& Hirose, K. (1974) Clinical study of gout and hyperuricemia: Epidemiology and pathogenesis. Rheum, 14, 95-105.

[4] The Ministry of Health, Labour and Welfare. Household Statistics Office. (2020) Comprehensive Survey of Living Conditions [Internet]. Available from: https://www.mhlw.go.jp/toukei/list/20-21kekka.html.

[5] Khanna, D., Fitzgerald, J. D., Khanna, P. P., Bae, S., Singh, M. K., Neogi, T., Pillinger, M. H., Merill, J., Lee, S., Prakash, S., Kaldas, M., Gogia, M., Perez-Ruiz, F., Taylor, W., Lioté, F., Choi, H., Singh, J. A., Dalbeth, N., Kaplan, S., Niyyar, V., Jones, D., Yarows, S. A., Roessler, B., Kerr, G., King, C., Levy, G., Furst, D. E., Edwards, N. L., Mandell, B., Schumacher, H. R., Robbins, M., Wenger, N., \& Terkeltaub, R. (2012) 2012 American College of Rheumatology guidelines for management of gout. Part 1: systematic nonpharmacologic and pharmacologic therapeutic approaches to hyperuricemia. Arthritis Care Research, 64, 1431-1446.

[6] Hisatome, I., Ichida, K., Mineo, I., Ohtahara, A., Ogino, K., Kuwabara, M., Ishizaka, N., Uchida, S., Kurajoh, M., Kohagura, K., Sato, Y., Taniguchi, A., Tsuchihashi, T., Terai, C., Nakamura, T., Hamaguchi, T., Hamada, T., Fujimori, S., Masuda, I., Moriwaki, Y., Yamamoto, T. on behalf of guideline development group. (2018) Japanese Society of Gout and Uric \& Nucleic Acids Guidelines for Management of Hyperuricemia and Gout: 3 rd edition. SHINDAN TO CHIRYO SHA, Inc. pp. 1-169. Tokyo (in Japanese).

[7] Zhu, Y., Pandya, B. J., \& Choi, H. K. (2012) Comorbidities of gout and hyperuricemia in the US general population: NHANES 2007-2008. Am J Med, 125, 679-687. 
[8] Tana, C., Ticinesi, A., Prati, B., Nouvenne, A. \& Meschi, T. (2018) Uric acid and cognitive function in older individuals. Nutrients, 10, 975.

[9] Lin, K-M., Lu, C-L., Hung, K-C., Wu, P-C., Pan, C-F., Wu, C-J., Syu, R-S., Chen, J-S., Hsiao, P-J., \& Lu, K-C. (2019) The paradoxical role of uric acid in osteoporosis. Nutrients, 11, 2111.

[10] Koguchi, T. (2021) Modification of dietary habits for prevention of gout in Japanese people: Gout and macronutrient intake. Am J Health Res, (in press).

[11] Koguchi, T. (2021) Modification of dietary habits for prevention of gout in Japanese people: Gout and micronutrient intake or alcohol consumption. Am J Health Res, (in press).

[12] Koguchi, T. (2021) Modification of dietary habits for prevention of gout in Japanese people: Gout and food intake. Am J Health Res, (in press).

[13] Waslien, C. I., Calloway, D. H., \& Margen, S. (1968) Uric acid production of men fed graded amounts of egg protein and yeast nucleic acid. Am J Clin Nutr, 21, 892-897.

[14] Matzkies, F., Berg, G., \& Mädl, H. (1980) The uricosuric action of protein in man. Adv Exp Med Biol, 122A, 227-231.

[15] Gibson, T., Rodgers, A. V., Simmonds, H. A., Court-Brown, F., Todd, E., \& Meilton, V. (1983) A controlled study of diet in patients with gout. Ann Rheum Dis, 42, 123-127.

[16] Lewis, H. B., \& Doisy, E. A. (1918) Studies in uric acid metabolism. I. The influence of high protein diets on the endogenous uric acid elimination. J Biol Chem, 36, 1-7.

[17] Raiziss, G. W., Dubin, H., \& Ringer, A. I. (1914) Studies in endogenous uric acid metabolism. J Biol Chem, 19, 473-485.

[18] Jenkins, D. J., Kendall, C. W., Vidgen, E., Augustin, L. S., van Erk, M., Geelen, A., Parker, T., Faulkner, D., Vuksan, V., Josse, R. G., Leiter, L. A., \& Connelly, P. W. (2001) High-protein diets in hyperlipidemia: effect of wheat gluten on serum lipids, uric acid, and renal function. Am J Clin Nutr, 74, 57-63.

[19] Teng, G. G., Pan, A., Yuan, J. M., \& Koh, W. P. (2015) Food sources of protein and risk of incident gout in the Singapore Chinese Health Study. Arthritis Rheumatol, 67, 1933-1942.

[20] Nicholls, A., \& Scott, J. T. (1972) Effect of weight-loss on plasma and urinary levels of uric acid. Lancet, 2, 1223-1224.

[21] Fam, A. G. (2002) Gout, diet, and the insulin resistance syndrome. J Rheumatol, 29, 1350-1355.

[22] Terkeltaub, R., \& Edwards, N. L. (2013) Gout: Diagnosis and management of gouty arthritis and hyperuricemia. 3rd edition, p. 1-336. Professional Communications, Inc. NY.

[23] Vuorinen-Markkola, H., \& Yki-Järvinen, H. (1994) Hyperuricemia and insulin resistance. J Clin Endocrinol Metab, $78,25-29$.

[24] Underwood, M. (2006) Diagnosis and management of gout. BMJ, 332, 1315-1319.

[25] Schlesinger, N. (2005) Dietary factors and hyperuricemia. Curr Pharm Des, 11, 4133-4138.

[26] Kaneko, K., Aoyagi, Y., Fukuuchi, T., Inazawa, K., \& Yamaoka, N. (2014) Total purine and purine base content of common foodstuffs for facilitating nutritional therapy for gout and hyperuricemia. Biol Pharm Bull, 37, 709-721.
[27] Zhang, X., La, Q., Zhang, Z., Chen, Y., Wang, Y., Wang, Y., Li, Z., \& Jiang, L. (2018) Value of three-dimensional speckle tracking echocardiography to assess left ventricular function in hyperuricemia patients. Clin Rheumatol, 37, 2539-2545.

[28] Liu, Z., Que, S., Zhou, L., \& Zheng, S. (2018) Dose-response relationship of serum uric acid with metabolic syndrome and non-alcoholic fatty liver disease incidence: a meta-analysis of prospective studies. Sci Rep, 5, 14325.

[29] Bowering, J., Calloway, D. H., Margen, S., \& Kaufmann, N. A. (1970) Dietary protein level and uric acid metabolism in normal man. J Nutr, 100, 249-261.

[30] Edozien, J. C., Udo, U. U., Young, V. R., \& Scrimshaw, N. S. (1970) Effects of high levels of yeast feeding on uric acid metabolism of young men. Nature, 228, 180.

[31] Yü, T. F., Berger, L., \& Gutman, A. B. (1962) Renal function in gout. II. Effect of uric acid loading on renal excretion of uric acid. Am J Med, 33, 829-844.

[32] Protein-Calorie Advisory Group of the United Nations System. (1975) PAG ad hoc working group on clinical evaluation and acceptable nucleic acid levels of SCP for human consumption. PAG Bull, 5, 17-26.

[33] Clifford, A. J., Riumallo, J. A., Young, V. R., \& Scrimshaw, N. S. (1976) Effect of oral purines on serum and urinary uric acid of normal, hyperuricemic and gouty humans. J Nutr, 106, 428-434.

[34] Brulé, D., Sarwar, G., Savoie, L., Campbell, J., \& Zeggelaar, M. V. (1988) Differences in uricogenic effects of dietary purine bases, nucleosides and nucleotides in rats. J Nutr, 118, 780-786.

[35] Yokozawa, T., Oura, H., Nakagawa, H., \& Fukuda, H. (1981) Metabolic effects of dietary adenine in rats. Nippon Nogeikagaku Kaishi (J Jpn Soc Biosci Biotech Agrochem), 55, 811-816 (in Japanese).

[36] Yokozawa, T., Oura, H., Nakagawa, H., \& Okada, T. (1982) Adenine-induced hyperuricemia and renal damage in rats. J Jpn Soc Biosci Biotech Agrochem, 56, 655-663 (in Japanese).

[37] Koguchi, T., Koguchi, H., Nakajima, H., Takano, S., Yamamoto, Y., Innami, S., Maekawa, A., \& Tadokoro, T. (2004) Dietary fiber suppresses elevation of uric acid and urea nitrogen concentrations in serum of rats with renal dysfunction induced by dietary adenine. Int J Vitam Nutr Res, 74, 253-263.

[38] Havlik, J., Plachy, V., Fernandez, J., \& Rada, V. (2010) Dietary purines in vegetarian meat analogues. J Sci Food Agric, 90, 2352-2357.

[39] Zhang, Y., Chen, C., Choi, H., Chaisson, C., Hunter, D., Niu, J., $\&$ Neogi, T. (2012) Purine-rich foods intake and recurrent gout attacks. Ann Rheum Dis, 71, 1448-1453.

[40] FitzGerald, J. D., Dalbeth, N., Mikuls, T., Brignardello-Petersen, R., Guyatt, G., Abeles, A. M., Gelber, A. C., Harrold, L. R., Khanna, D., King, C., Levy, G., Libbey, C., Mount, D., Pillinger, M. H., Rosenthal, A., Singh, J. A., Sims, J. E., Smith, B. J., Wenger, N. S., Bae, S. S., Danve, A., Khanna, P. P., Kim, S. C., Lenert, A., Poon, S., Qasim, A., Sehra, S. T., Sharma, T. S. K., Toprover, M., Turgunbaev, M., Zeng, L., Zhang, M. A., Turner, A. S., \& Neogi, T.(2020) 2020 American College of Rheumatology guideline for the management of gout. Arthritis Care Research, 72, 744-760. 
[41] Richette, P., Doherty, M., Pascual, E., Barskova, V., Becce, F., Castaneda-Sanabria, J. Coyfish, M., Guillo, S., Jansen, T. L., Jansens, H., Lioté, F., Mallen, C., Nuki, G., Perez-Ruiz, F., Pimentao, J., Punzi, L., Pywell, T., So, A., Tausche, A. K., Uhlig, T., Zavada, J., Zhang, W., Tubach, F., \& Bardin, T. (2017) 2016 updated EULAR evidence-based recommendations for the management of gout. Ann Rheum Dis, 76, 29-42.

[42] Hui, M., Carr, A., Cameron, S., Davenport, G., Doherty, M., Forrester, H., Jenkins, W., Jordan, K. N., Mallen, C. D., McDonald, T. M., Nuki, G., Pywell, A., Zhang, W., Roddy, E., British Society for Rheumatology Standard, Audit and Guidelines Working Group. (2017) The British Society for Rheumatology Guideline for the Management of Gout. Rheumatology, 56, 1056-1059.

[43] Japanese Urological Association., Japanese Society of Endourology., Japanese Society on Urolithiasis Research. (2013) Guidelines for Management of Urolithiasis.: 2 nd edition, pp. 93-116, Kanehara shuppan, Tokyo (in Japanese).

[44] Zhang, M., Gao, Y., Wang, X., Liu, W., Zhang, Y., \& Huang, G. (2016) Comparison of the effect of high fruit and soybean products diet and standard diet interventions on serum uric acid in asymptomatic hyperuricemia adults: an open randomized controlled trial. Int J Food Sci Nutr, 67, 335-343.

[45] Kanbara, A., Miura, Y., Nyogo, H., Chayama, K., \& Seyama, I. (2012) Effect of urine pH changed by dietary intervention on uric acid clearance mechanism of $\mathrm{pH}$-dependent excretion of urinary uric acid. Nutr J, 11, 39.

[46] Kanbara, A., \& Seyama, I. (2011) Effect of urine pH on uric acid excretion by manipulating food materials. Nucleosides Nucleotides Nucleic Acids, 30, 1066-1071.

[47] Dessein, P. H., Shipton, E. A., Stanwix, A. E., Joffe, B. I., \& Ramokgadi, J. (2000) Beneficial effects of weight loss associated with moderate calorie/carbohydrate restriction, and increased proportional intake of protein and unsaturated fat on serum urate and lipoprotein levels in gout: a pilot study. Ann Rheum Dis, 59, 539-543.

[48] Beydoun, M. A., Fanelli-Kuczmarski, M. T., Canas, J-A., Beydoun, H. A., Evans, M. K., \& Zonderman, A. B. (2018) Dietary factors are associated with serum uric acid trajectory differentially by race among urban adults. Br J Nutr, 120, 935-945.

[49] Tsai, Y. T., Liu, J. P., Tu, Y, K., Lee, M. S., Chen, P. R., Hsu, H. C., Chen, M. F., \& Chien, L. L. (2012) Relationship between dietary patterns and serum uric acid concentrations among ethnic Chinese adults in Taiwan. Asia Pac J Clin Nutr, 21, 263-270.

[50] Zhang, M., Chang, H., Gao, Y., Wang, X., Xu, W., Liu, D., Li, G., \& Huang, G. (2012) Major dietary patterns and risk of asymptomatic hyperuricemia in Chinese adults. J Nutr Sci Vitaminol, 58, 339-345.

[51] Xia, Y., Xiang, Q., Gu, Y., Jia, S., Zhang, Q., Liu, L., Meng, G., Wu, H., Bao, X., Yu, B., Sun, S., Wang, X., Zhou, M., Jia, Q., Wu, Y., Song, K., \& Niu, K.(2018) A dietary pattern rich in animal organ, seafood and processed meat products is associated with newly diagnosed hyperuricaemia in Chinese adults: a propensity score-matched case-control study. Br J Nutr, 119, 1177-1184.

[52] Rai, S. K., Fung, T. T., Lu, N., Keller, S. F., Curhan, G. C., \& Choi, H. K. (2017) The dietary approaches to Stop Hypertension (DASH) diet, Western diet, and risk of gout in men: prospective cohort study. BMJ, 357, j1794.
[53] Kramer, H. (2017) Kidney disease and the Westernization and industrialization of food. Am J Kidney Dis, 70, 111-121.

[54] Ajani, U. A., Ford, E. S., \& Mokdad, A. H. (2004) Dietary fiber and C-reactive protein: findings from national health and nutrition examination survey data. J Nutr, 134, 1181-1185.

[55] Ma, Y. S., Griffith, J. A., Chasan-Taber, L., Olendzki, B. C., Jackson, E., Stanek, E. J., Li, W. J., Pagoto, S. L., Hafner, A. R., \& Ockene, I. S. (2006) Association between dietary fiber and serum C-reactive protein. Am J Clin Nutr, 83, 760-766.

[56] Esmaillzadeh, A., \& Azadbakht, L. (2012) Legume consumption is inversely associated with serum concentrations of adhesion molecules and inflammatory biomarkers among Iranian women. J Nutr, 142, 334-339.

[57] Hariharan, D., Vellanki, K., \& Kramer, H. (2015) The western diet and chronic kidney disease. Curr Hypertens Rep, 17, 16.

[58] Chang, W. C. (2011) Dietary intake and the risk of hyperuricemia, gout and chronic kidney disease in elderly Taiwanese men. Aging Male, 14, 195-202.

[59] Lin, J., Fung, T. T., Hu, F. B., \& Curhan, G. C. (2011) Association of dietary patterns with albuminuria and kidney function decline in older white women: a subgroup analysis from the Nurses's Health Study. Am J kidney Dis, 57, 245-254.

[60] van Dam, R. M., Rimm, E. B., Willett, W. C., Stampfer, M. J., $\& \mathrm{Hu}, \mathrm{F}$. B. (2002) Dietary patterns and risk for type 2 diabetes mellitus in U.S. men. Ann Intern Med, 136, 201-209.

[61] Hu, F. B., Rimm, E. B., Stampfer, M. J., Ascherio, A., Spiegelman, D., \& Willett, W. C. (2000) Prospective study of major dietary patterns and risk of coronary heart disease in men. Am J Clin Nutr, 72, 912-921.

[62] Mehmood, A., Zhao, I., Wang, C., Nadeem, M., Raza, A., Ali, N., \& Shah, A. A. (2019) Management of hyperuricemia through dietary polyphenols as a natural medicament: A comprehensive review. Crit Rev Food Sci Nutr, 59, 1433-1455.

[63] Wang, Y., Zhu, J. X., Kong, L. D., Yang, C., Cheng, C. H., \& Zhang, X. (2004) Adminstration of procyanidins from grape seeds reduces serum uric acid levels and decreases hepatic xanthine dehydrogenase/oxidase activities in oxonate-treated mice. Basic Clin Pharmacol Toxicol, 94, 232-237.

[64] Mo, S. F., Zhou, F., Lv, Y. Z., Hu, Q. H., Zhang, D. M., \& Kong, L. D. (2007) Hypouricemic action of selected flavonoids in mice: structure-activity relationships. Biol Pharm Bull, 30, 1551-1556.

[65] Lin, C. M., Chen, C. S., Chen, C. T., Liang, Y. C., \& Lin, J. K. (2002) Molecular modeling of flavonoids that inhibits xanthine oxidase. Biochem Biophys Res Commun, 294, 167-172.

[66] Pauff, J. M., \& Hille, R. (2009) Inhibition studies of bovine xanthine oxidase by luteolin, silibinin, quercetin, and curcumin. J Nat Prod, 72, 725-731.

[67] Chan, W. S., Wen, P. C., \& Chiang, H. C. (1995) Structure-activity relationship of caffeic acid analogues on xanthine inhibition. Anticancer Res, 15, 703-705.

[68] Flemmig, J., Kuchta, K., Arnhold, J., \& Rauwald, H. W. (2011) Olea europaea leaf (Ph. Eur.) extract as well as several of its isolated phenolics inhibit the gout-related enzyme xanthine oxidase. Phytomedicine, 15, 561-566. 
[69] Butt, M. S., Imran, A., Sharif, M. K., Ahmad, R. S., Xiao, H., Imran, M., \& Rsool, H. A. (2014) Black tea polyphenols: a mechanistic treatise. Crit Rev Food Sci Nutr, 54, 1002-1011.

[70] Aucamp, J., Gaspar, A., Hara, Y., \& Apostolides, Z. (1997) Inhibition of xanthine oxidase by catechins from tea (Camellia sinensis). Anticancer Res, 17 (6D), 4381-4385.

[71] Shi, Y., \& Williamson, G. (2016) Quercetin lowers plasma uric acid in pre-hyperuricaemic males: a randomised double-blinded, placebo-controlled, cross-over trial. Br J Nutr, $115,800-806$.

[72] Liu, J., Sun, L. L. He, L. P., Ling, W. H., Liu, Z. M., \& Chen, M (2014) Soy food consumption, cardiometabolic alterations and carotid intima-media thickness in Chinese adults. Nutr Metab Cardiovasc Dis, 24, 1097-1104.

[73] INRA (2021) Phenol-Explorer database [Internet]. Available from: http://phenol-explorer.eu/compounds.

[74] Kuhnau, J. (1976) The flavonoids. A class of semi-essential food components: their role in human nutrition. World Rev Nutr Diet, 24, 117-191.

[75] Yoon, J-H., \& Baek, S. J. (2005) Molecular targets of dietary polyphenols with anti-inflammatory properties. Yonsei Med J, 46, 585-596.

[76] Ríos-Hoyo, A., Cortés, M. J., Ríos-Ontiveros, H., Meaney, E., Ceballos, G., \& Gutiérrez-Salmeán, G. (2014) Obesity, metabolic syndrome, and dietary therapeutical approaches with a special focus on nutraceuticals (polyphenols): a mini-review. Int J Vitam Nutr Res, 84, 113-123.

[77] Vendrame, S., \& Klimis-Zacas, D. (2015) Anti-inflammatory effect of anthocyanins via modulation of nuclear factor- $\kappa \mathrm{B}$ and mitogen-activated protein kinase signaling cascades. Nutr Rev, 73, 348-358.

[78] Joven, J., Micol, V., Segura-Carretero, A., Alonso-Villaverde, C., \& Menéndez, J. A. (2014) Bioactive food components platform. Polyphenols and the modulation of gene expression pathways: can we eat our way out of the danger of chronic disease? Crit Rev Food Sci Nutr, 54, 985-1001.

[79] Mena, M. P., Sacanella, E., Vazquez-Agell, M., Morales, M., Fitó, M., Escoda, R., Serrano-Martinez, M., Salas-Salvadó, J., Benages, N., Casas, R., Lamuela-Raventós, R. M., Masanes, F., Ros, E., \& Estruch, R. (2009) Inhibition of circulating immune cell activation: a molecular antiinflammatory effect of the Mediterranean diet. Am J Clin Nutr, 89, 248-256.

[80] Medina-Remón, A., Casas, R., Tresserra-Rimbau, A., Ros, E., Martínez-González, M. A., Fitó, M., Corella, D., Salas-Salvadó, J., Lamuela-Raventos, R. M., Estruch, R., \& on behalf of the PREDIMED Study Investigators. (2017) Polyphenol intake from a Mediterranean diet decreases inflammatory biomarkers related to atherosclerosis: a substudy of the PREDIMED trial. Br J Clin Pharmacol, 83, 114-128.

[81] Guasch-Ferré, M., Bulló, M., Babio, N., Martínez-González, M A., Estruch, R., Covas, M-I., Wärnberg, J., Arós, F., Lapetra, J., Serra-Majem, L., Basora, J., \& Salas-Salvadó, J. (2013) Mediterranean diet and risk of hyperuricemia in elderly participants at high cardiovascular risk. J Gerontol A Biol Sci Med Sci, 68, 1263-1270.

[82] Sánchez-Moreno, C., Cano, M. P., de Ancos, B., Plaza, L., Olmedilla, B., Granado, F., \& Martín, A. (2004) Consumption of high-pressurized vegetable soup increases plasma vitamin C and decreases oxidative stress and inflammatory biomarkers in healthy humans. J Nutr, 134, 3021-3025.

[83] Chatzipavlou, M., Magiorkinis, G., Koutsogeorgopoulou, L., \& Kassimos, D. (2014) Mediterranean diet intervention for patients with hyperuricemia: a pilot study. Rheumatol Int, 34, 759-762.

[84] Kontogianni, M. D., Chrysohoou, C., Panagiotakos, D. B., Tsetsekou, E., Zeimbekis, A., Pitsavos, C., \& Stefanadis, C. (2012) Adherence to the Mediterranean diet and serum uric acid: the ATTICA study. Scand J Rheumatol, 41, 442-449.

[85] Chrysohoou, C., Skoumas, J., Pitsavos, C., Masoura, C., Siasos, G., Galiatsatos, N., Psaltopoulou, T., Mylonakis, C., Margazas, A., Kyvelou, S., Mamatas, S., Panagiotakos, D. B., \& Stefanadis, C. (2011) Long-term adherence to the Mediterranean diet reduces the prevalence of hyperuricemia in elderly individuals, without known cardiovascular disease: the Ikaria study. Maturitas, 70, 58-64.

[86] Alkerwi, A., Vernier, C., Crichton, G. E., Sauvageot, N., Shivappa, N., \& Hébert, J. R. (2015) Cross-comparison of diet quality indices for predicting chronic disease risk: findings from the Observation of Cardiovascular Risk actors in Luxembourg (ORISCAV-LUX) study. Br J Nutr, 113, 259-269.

[87] Bulló, M., Lamuela-Raventós, R., \& Salas-Salvadó, J. (2011) Mediterranean diet and oxidation: nuts and olive oil as important sources of fat and antioxidants. Curr Top Med Chem, 11, 1797-1810.

[88] Estruch, R., Martínez-González, M. A., Corella, D., Salas-Salvadó, J., Ruiz-Gutiérrez, V., Covas, M. I., Fiol, M., Gómez-Gracia, E., López-Sabater, M. C., Vinyoles, E., Arós, F., Conde, M., Lahoz, C., Lapetra, J., Sáez, G., \& Ros, E.; PREDIMED Study Investigators. (2006) Effects of a Mediterranean-style diet on cardiovascular risk factors: a randomized trial. Ann Intern Med, 145, 1-11.

[89] Estruch, R., Ros, E., Salas-Salvado, J., Covas, M. I., Corella, D., Aros, F., Gómez-Gracia, E., Ruiz-Gutiérrez, V., Fiol, M., Lapetra, J., Lamuela-Raventos, R. M., Serra-Majem, L., Pintó, X., Basora, J., Muñoz, M. A., Sorlí, J. V., Martínez, J. A., Fitó, M., Gea, A., Hernán, M. A., \& Martínez-González, M. A. (2018) Primary prevention of cardiovascular disease with a Mediterranean diet supplemented with extra-virgin olive oil or nuts. New Engl J Med, 378, e34.

[90] Skoldstam, L., Hagfors, L., \& Johansson, G. (2003) An experimental study of a Mediterranean diet intervention for patients with rheumatoid arthritis. Ann Rheum Dis, 62, 208-214.

[91] Psaltopoulou, T., Naska, A., Orfanos, P., Trichopoulos, D., Mountokalakis, T., \& Trichopoulou, A. (2004) Olive oil, the Mediterranean diet, and arterial blood pressure: the Greek European Prospective Investigation into Cancer and Nutrition (EPIC) study. Am J Clin Nutr, 80, 1012-1018.

[92] Smyth, A., Griffin, M., Yusuf, S., Mann, J. F., Reddan, D., Canavan, M., Newell, J., \& O'Donnell, M. (2016) Diet and major renal outcomes: A prospective cohort study. The NIH-AARP Diet and Health Study. J Ren Nutr, 26, 288-298.

[93] Huang, X., Jiménez-Moleón, J. J., Lindholm, B., Cederholm, T., Arnlöv, J., Risérus, U., Sjögren, O., \& Carrero, J. J. (2013) Mediterranean diet, kidney function, and mortality in men with CKD. Clin J Am Soc Nephrol, 8, 1548-1555. 
[94] Hu, E. A., Steffen, L. M., Grams, M. E., Crews, D. C., Coresh, J., Appel, L. J., \& Rebholz, C. M. (2019) Dietary patterns and risk of incident chronic kidney disease: the Atherosclerosis Risk in Communities study. Am J Clin Nutr, 110, 713-721.

[95] Tyrovolas, S., Bountziouka, V., Papairakleous, N., Zeimbekis, A., Anastassiou, F., Gotsis, E., Metallinos, G., Polychronopoulos, E., Lionis, C., \& Panagiotakos, D. (2009) Adherence to the Mediterranean diet is associated with lower prevalence of obesity among elderly people living in Mediterranean islands: the MEDIS study. Int J Food Sci Nutr, 60 Suppl 6, 137-150.

[96] Gopinath, B., Harris, D. C., Flood, V. M., Burlutsky, G., Brand-Miller, J., \& Mitchell, P. (2011) Carbohydrate nutrition is associated with the 5-year incidence of chronic kidney disease. J Nutr, 141, 433-439.

[97] Tektonidis, T. G., Akesson, A., Gigante, B., Wolk, A., \& Larsson, S. C. (2015) A Mediterranean diet and risk of myocardial infarction, heart failure and stroke; A population-based cohort study. Atherosclerosis, 243, 93-98.

[98] Psaltopoulou, T., Sergentanis, T. N., Panagiotakos, D. B., Sergentanis, I. N., Kosti, R., \& Scameas, N. (2013) Mediterranean diet, stroke, cognitive impairment, and depression: A meta-analysis. Ann. Neurol, 74, 580-591.

[99] Kontogianni, M. D., \& Panagiotakos, D. B. (2014) Dietary patterns and stroke: A systematic review and re-meta-analysis. Maturitas, 79, 41-47.

[100] Badimon, L., Chagas, P., \& Chiva-Blanch, G. (2019) Diet and cardiovascular disease: Effects of foods and nutrients in classical and emerging cardiovascular risk factors. Curr Med Chem, 26, 3639-3651.

[101] Sofi, F., Cesari, F., Abbate, R., Gensini, G. F., \& Casini, A. (2008) Adherence to Mediterranean diet and health status: meta-analysis. BMJ, 337, a1344.

[102] Solfrizzi, V., Custodero, C., Lozupone, M., Imbimbo, B. P., Valiani, V., Agosti, P., Schilardi, A., D'Introno, A., La Montagna, M., Calvani, M., Guerra, V., Sardone, R., Abbrescia, D., Bellomo, A., Greco, A., Paniele, A., Seripa, D., Logroscino, G., Sabbá, C., \& Panza, F. (2017) Relationships of dietary patterns, foods, and micro-and macronutrients with Alzheimer's disease and late-life cognitive disorders: A systematic review. J Alzheimers Dis, 59, 815-849.

[103] Barros, R., Moreira, A., Fonseca, J., de Oliveira, J. F., Delgado, L., Castel-Branco, M. G., Haahtela, T., Lopes, C., \& Moreira, P (2008) Adherence to the Mediterranean diet and fresh fruit intake are associated with improved asthma control. Allergy, 63, 917-923.

[104] Cespedes, E. M., Hu, F. B., Tinker, L., Rosner, B., Redline, S., Garcia, L., Hingle, M., Van Horn, L., Howard, B. V., Levitan, E. B., Li, W., Manson, J. E., Phillips, L. S., Rhee, J. J., Waring, M. E., \& Neuhouser, M. L. (2016) Multiple healthful dietary patterns and type 2 diabetes in the women's health initiative. Am J Epidemiol, 183, 622-633.

[105] Reedy, J., Krebs-Smith, S. M., Miller, P. E., Liese, A. D., Kahle, L. L., Park, Y., \& Subar, A. F. (2014) Higher diet quality is associated with decreased risk of all-cause, cardiovascular disease, and cancer mortality among older adults. J Nutr, 144, 881-889.

[106] Ikizler, T. A., Burrowes, J. D., Byham-Gray, L. D., Campbell, K. L., Carrero, J-J., Chan, W., Fouque, D., Friedman, A. N.,
Ghaddar, S., Goldstein-Fuchs, D. J., Kaysen, G. A., Kopple, J. D., Teta, D., Wang, A. Y-M., \& Cuppari, L. (2020) KDOQI clinical practice guideline for nutrition in CKD: 2020 update. Am J Kidney Dis, 76, S1-S107.

[107] American Diabetes Association (2019) Lifestyle management: standards of medical care in diabetes-2019. Diabetes Care, 42, S46-S60.

[108] Forouhi, N. G., Misra, A., Mohan, V., Taylor, R., \& Yancy, W. (2018) Dietary and nutritional approaches for prevention and management of type 2 diabetes. BMJ, 361, k2234.

[109] Saura-Calixto, F., \& Goñi, I. (2009) Definition of the Mediterranean diet based on bioactive compounds. Crit Rev Food Sci Nutr, 49, 145-152.

[110] Vedder, D., Walrabenstein, W., Heslinga, M., de Vries, R., Nurmohamed, M., van Schaardenburg, D., \& Gerritsen, M. (2019) Dietary interventions for gout and effect on cardiovascular risk factors: A systematic review. Nutrients, 11, 2955.

[111] Beunza, J. J., Toledo, E., Hu, F. B., Bes-Rastrollo, M., Serrano-Martínez, M., Sánchez-Villegas, A., Martínez, J. A., \& Martínez-González, M. A. (2011) Adherence to the Mediterranean diet, long-term weight change, and incident overweight or obesity: the Seguimiento Universidad de Navarra (SUN) cohort. Am J Clin Nutr, 93, 675-684.

[112] Romaguera, D., Norat, T., Vergnaud, A. C., Mouw, T., May, A. M., Agudo, A., Buckland, G., Slimani, N., Rinaldi, S., Couto, E., Clavel-Chapelon, F., Boutron-Ruault, M. C., Cottet, V., Rohrmann, S., Teucher, B., Bergmann, M., Boeing, H., Tjønneland, A., Halkjaer, J., Jakobsen, M. U., Dahm, C. C., Travier, N., Rodriguez, L., Sanchez, M. J., Amiano, P., Barricarte, A., Huerta, J. M., Luan, J., Wareham, N., Key, T. J., Spencer, E. A., Orfanos, P., Naska, A., Trichopoulou, A., Palli, D., Agnoli, C., Mattiello, A., Tumino, R., Vineis, P., Boeno-de-Mesquita, H. B., Büchner, F. L., Manjer, J., Wirfält, E., Johansson, I., Hellstrom, V., Lund, E., Braaten, T., Engeset, D., Odysseos, A., Riboli, E., \& Peeters, P. H. (2010) Mediterranean dietary patterns and prospective weight change in participants of the EPIC-PANACEA study. Am J Clin Nutr, 92, 912-921.

[113] Mitrou, P. N., Kipnis, V., Thiebaut, A. C., Reedy, J., Subar, A. F., Wirfält, E., Flood, A., Mouw, T., Hollenbeck, A. R., Leitzmann, M. F., \& Schatzkin, A. (2007) Mediterranean dietary pattern and prediction of all-cause mortality in a US population: results from the NIH-AARP Diet and Health Study. Arch Intern Med, 167, 2461-2468.

[114] Appel, L. J., Moore, T. J., Obarzanek, E., Vollmer, W. M., Svetkey, L. P., Sacks, F. M., Bray, G. A., Vogt, T. M., Cutler, J. A., Windhauser, M. M., Lin, P. H., \& Karanja, N. (1997) A clinical trial of the effects of dietary patterns on blood pressure. DASH Collaborative Research Group. N Engl J Med, 336, 1117-1124.

[115] Karanja, N. M., Obarzanek, E., Lin, P. H., McCullough, M. L., Phillips, K. M., Swain, J. F., Champagne, C. M., \& Hoben, K. $P$ (1999) Descriptive characteristics of the dietary patterns used in the Dietary Approaches to Stop Hypertension Trial. DASH Collaborative Research Group. J Am Diet Assoc, 99 (Suppl), 519-527.

[116] Campbell, A. P. (2017) DASH eating plan: an eating pattern for diabetes management. Diabetes Spectr, 30, 76-81.

[117] Skerret, P. J., \& Willett, W. C. (2010) Essentials of healthy eating: A guide. J Midwifery Womens Health, 55, 492-501. 
[118] Juraschek, S. P., Gelber, A. C., Choi, H. K., Appel, L. J., \& Miller, E. R. 3rd. (2016) Effects of the Dietary Approaches to Stop Hypertension (DASH) Diet and Sodium Intake on Serum Uric Acid. Arthritis Rheumatol, 68, 3002-3009.

[119] Juraschek, S. P., White, K., Tang, O., Yeh, H-C., Cooper, L. A., \& Miller, E. R. 3rd. (2018) Effects of a Dietary Approaches to Stop Hypertension (DASH) diet intervention on serum uric acid in African Americans with hypertension. Arthritis Care Res, 70, 1509-1516.

[120] Tang, O., Miller, E. R. 3rd., Gelber, A. C., Choi, H. K., Appel, L. J., \& Juraschek, S. P. (2017) DASH diet and change in serum uric acid over time. Clin Rheumatol, 36, 1413-1417.

[121] Rebholz, C. M., Crews, D. C., Grams, M. E., Steffen, L. M., Levey, A. S., Miller, E. R. 3 rd., Appel, L. J., \& Coresh, J. (2016) DASH (Dietary Approaches to Stop Hypertension) diet and risk of subsequent kidney disease. Am J kidney Dis, 68, 853-861.

[122] Liese, A. D., Nichols, M., Sun, X., D’Agostino, R. B. Jr., \& Haffner, S. M. (2009) Adherence to the DASH diet is inversely associated with incidence of type 2 diabetes: the insulin resistance atherosclerosis study. Diabetes Care, 32, 1434-1436.

[123] Fung, T. T., Chiuve, S. E., McCullough, M. L., Rexrode, K. M., Logroscino, G., \& Hu, F. B. (2008) Adherence to a DASH-style diet and risk of coronary heart disease and stroke in women. Arch Intern Med, 168, 713-720.

[124] Taylor, E. N., Fung, T. T., \& Curhan, G. C. (2009) DASH-Style diet associates with reduced risk for kidney stones. J Am Soc Nephrol, 20, 2253-2259.

[125] Soltani, S., Arablou, T., Jayedi, A., \& Salehi-Abargouei, A. (2020) Adherence to the dietary approaches to stop hypertension (DASH) diet in relation to all-cause and cause-specific mortality: a systematic review and dose-response meta-analysis of prospective cohort studies. Nutr J, 19, 37.

[126] Saneei, P., Salehi-Abargouei, A., Esmaillzadeh, A., \& Azadbakht, L. (2014) Influence of Dietary Approaches to Stop Hypertension (DASH) diet on blood pressure: a systematic review and meta-analysis on randomized controlled trials. Nutr Metab Cardiovasc Dis, 24, 1253-1261.

[127] Siervo, M., Lara, J., Chowdhury, S., Ashor, A., Oggioni, C., \& Mathers, J. C. (2015) Effects of the Dietary Approaches to Stop Hypertension (DASH) diet on cardiovascular risk factors: a systematic review and meta-analysis. Br J Nutr, 113, 1-15.

[128] Obarzanek, E., Sacks, F. M., Vollmer, W. M., Bray, G. A., Miller, E. R., Lin, P. H., Karanja, N. M., Most-Windhauser, M. M., Moore, T. J. Swain, J. F., Bales, C. W., Proschan, M. A., DASH Research Group (2001) Effects on blood lipids of a blood pressure-lowering diet: The Dietary Approaches to Stop Hypertension (DASH) trial. Am J Clin Nutr, 74, 80-89.

[129] Unger, T., Borghi, C., Charchar, F., Khan, N. A., Poulter, N. R., Prabhakaran, D., Ramirez, A., Schlaich, M., Stergiou, G. S., Tomaszewski, M., Wainford, R. D., Williams, B., \& Schutte, A E. (2020) 2020 International Society of Hypertension global hypertension practice guidelines. Hypertension, 75, 1334-1357.

[130] Kidney Disease Outcomes Quality Initiative (K/DOQI). (2004) $\mathrm{K} / \mathrm{DOQI}$ clinical practice guidelines on hypertension and antihypertensive agents in chronic kidney disease. Am J Kidney Dis, 43, S1-S290.
[131] Chiu, T. H. T., Huang, H-Y., Chiu, Y-F., Pan, W-H., Kao, H-Y., Chiu, J. P. C., Lin, M-N., \& Lin, C-L. (2014) Taiwanese vegetarians and omnivores: dietary composition, prevalence of diabetes and IFG. PLoS One, 9, e88547.

[132] Orlich, M. J., Jaceldo-Siegl, K., Sabate, J., Fan, J., Singh, P. N., \& Fraser, G. E. (2014) Patterns of food consumption among vegetarians and non-vegetarians. Br J Nutr, 112, 1644-1653.

[133] Chiu, T. H. T., Liu, C. H., Chang, C. C., Lin, M. N., \& Lin, C. L. (2019) Vegetarian diet and risk of gout in two separate prospective cohort studies. Clin Nutr, 39, 837-844.

[134] Hafez, R. M., Abdel-Rahman, T. M., \& Naguib, R. M. (2017) Uric acid in plants and microorganisms: Biological applications and genetics-A review. J Adv Res, 8, 475-486.

[135] Kapoor, B., Kaur, G., Gupta, M., \& Gupta, R. (2017) Indian medicinal plants useful in treatment of gout: a review for current status and future prospective. Asian J Pharm Clin Res, 10, 407-416.

[136] Lee, Y-S., Kim, S-H., Yuk, H. J., \& Kim, D-S. (2018) DKB114, a mixture of Chrysanthemum Indicum Linne flower and Cinnamomum Cassia (L.) J. Presl Bark extracts, improves hyperuricemia through inhibition of xanthine oxidase activity and increasing urine excretion. Nutrients, 10, 1381.

[137] Zhou, L., Lin, L., Liu, X., Chen, P., Liu, L., Zhang, Y., Wu, Y., Pettigrew, J. C., Cheng, D., \& Yi, D. (2014) Systematic review and meta-analysis of the clinical efficacy and adverse effects of Chinese herbal decoction for the treatment of gout. PLoS ONE, 9, e85008.

[138] Tozser, J., \& Benko, S. (2016) Natural compounds as regulators of NLRP3 inflammasome-mediated IL-1beta production. Mediat Inflamm, 2016, 5460302.

[139] Joseph, S. V., Edirisingle, I., \& Burton-Freeman, B. M. (2016) Fruit polyphenols: a review of anti-inflammatory effects in humans. Crit Rev Food Sci Nutr, 56, 419-444.

[140] Ralston, J. C., Lyons, C. L., Kennedy, E. B., Kirwan, A. M., \& Roche, H. M. (2017) Fatty acids and NLRP3 inflammasome-mediated inflammation in metabolic tissues. Annu Rev Nutr, 37, 77-102.

[141] Siener, R., \& Hesse, A. (2003) The effect of a vegetarian and different omnivorous diets on urinary risk factors for uric acid stone formation. Eur J Nutr, 42, 332-337.

[142] Yokoyama, Y., Nishimura, K., Barnard, N. D., Takegami, M., Watanabe, M., Sekikawa, A., Okamura, T., \& Miyamoto, Y. (2014) Vegetarian diets and blood pressure: a meta-analysis. JAMA Intern Med, 174, 577-587.

[143]Chuang, S-Y., Chiu, T. H. T., Lee, C-Y., Liu, T-T., Tsao, C. K., Hsiung, C. A., \& Chiu, Y-F. (2016) Vegetarian diet reduces the risk of hypertension independent of abdominal obesity and inflammation: a prospective study. J Hypertens, $34,2164-2171$.

[144] Chiu, T. H. T., Pan, W-H., Lin, M-N., \& Lin, C-L. (2018) Vegetarian diet, change in dietary patterns and diabetes risk: a prospective study. Nutr Diabates, 8, 12.

[145] Tonstad, S., Stewart, K., Oda, K., Batech, M., Herring, R. P., \& Fraser, G. E. (2013) Vegetarian diets and incidence of diabetes in the adventist health study-2. Nutr Metab Cardiovasc Dis, 23, 292-299. 
[146] Crowe, F. L., Appleby, P. N., Travis, R. C., \& Key, T. J. (2013) Risk of hospitalization or death from ischemic heart disease among British vegetarians and nonvegetarians: results from the EPIC-Oxford cohort study. Am J Clin Nutr, 97, 597-603.

[147] Jakše, B., Jakše, B., Pajek, M., \& Pajek, J. (2019) Uric acid and plant-based nutrition. Nutrients, 11, 1736.

[148] Piepoli, M. F., Hoes, A. W., Agewall, S., Albus, C., Brotons, C., Catapano, A. L., Cooney, M-T., Corrà, U., Cosyns, B., Deaton, C., Graham, I., Hall, M. S., Hobbs, F. D. R., Løchen, M-L., Löllgen, H., Marques-Vidal, P., Perk, J., Prescott, E., Redon, J., Richter, D. J., Sattar, N., Smulders, Y., Tiberi, M., van der Worp, H. B., van Dis, I., \& Verschuren, W. H. M.(2016) 2016 European Guidelines on cardiovascular disease prevention in clinical practice. The Sixth Joint Task Force of the European Society of Cardiology and Other Societies on Cardiovascular Disease Prevention in Clinical Practice (constituted by representatives of 10 societies and by invited experts) Developed with the special contribution of the European Association for Cardiovascular Prevention \& Rehabilitation (EACPR). Eur Heart J, 37, 2315-2381.

[149] Umemura, S., Arima, H., Arima, S., Asayama, K., Dohi, Y., Hirooka, Y., Horio, T., Hoshide, S., Ikeda, S., Ishimitsu, T., Ito, M., Ito, S., Iwashima, Y., Kai, H., Kamide, K., Kanno, Y., Kashihara, N., Kawano, Y., Kikuchi, T., Kitamura, K., Kitazono, T., Kohara, K., Kudo, M., Kumagai, H., Matsumura, K., Matsuura, H., Miura, K., Mukoyama, M., Nakamura, S., Ohkubo, T., Ohya, Y., Okura, T., Rakugi, H., Saitoh, S., Shibata, H., Shimosawa, T., Suzuki, H., Takahashi, S., Tamura, K., Tomiyama, H., Tsuchihashi, T., Ueda, S., Uehara, Y., Urata, H., \& Hirawa, N. (2019) The Japanese Society of Hypertension Guidelines for the Management of Hypertension (JSH 2019). Hypertens Res, 42, 1235-1481.

[150] Arnett, D. K., Blumenthal, R. S., Albert, M. A., Buroker, A. B., Goldberger, Z. D., Hahn, E. J., Himmelfarb, C. D., Khera, A., Lloyd-Jones, D., McEvoy, J. W., Michos, E. D., Miedema, M. D., Muñoz, D., Smith Jr, S. C., Virani, S. S., Williams, K. A., Yeboah, J., \& Ziaeian, B. (2019) 2019 ACC/AHA Guideline on the primary prevention of cardiovascular disease. Circulation, 140, e596-e646.

[151] World Health Organization (2007) Prevention of cardiovascular disease. Guidelines for assessment and management of cardiovascular risk. pp. 1-86. WHO Press. Geneva, Switzerland.

[152] Türk, C., Neisius, A., Petrik, A., Seitz, C., Skolarikos, A., Thomas, K., Donaldson, J. F., Drake, T., Grivas, N., \& Ruhayel, Y. (2018) EAU Guidelines on Urolithiasis. European Association of Urology 2018. EAU Guidelines. Edn. Presented at the EAU Annual Congress London 2018. ISBN
978-94-92671-01-1. EAU Guidelines office, Arnhem, The Netherlands [Internet]. Available from: http://uroweb.org/guidelines/compilations-of-all-guidelines/.

[153] Araki, E., Goto, A., Kondo, T., Noda, M., Noto, H., Origasa, H., Osawa, H., Taguchi, A., Tanizawa, Y., Tobe, K., \& Yoshioka, N. (2020) Japanese clinical practice guideline for diabetes 2019 Diabetology International, 11, 165-223.

[154] Japanese Society of Nephrology. (2018) Evidence-based clinical practice guideline for CKD 2018. pp. 1-133. Tokyo Igakusha. Tokyo (in Japanese).

[155] Kawasaki, T. (2007) Epidemiology of gout. Rheumatoid arthritis seminar XVIII (Shichikawa, K., ed.), pp. 51-57. Nagai Shoten Co., Ltd. Osaka (in Japanese).

[156] Roman, Y. M. (2019) Perspectives on the epidemiology of gout and hyperuricemia. Hawaii J Med Public Health, 78, 71-76.

[157] Burke, B. T., Köttgen, A., Law, A., Windham, B. G., Segev, D., Baer, A. N., Coresh, J., \& McAdams-DeMarco, M. A. (2015) Physical function, hyperuricemia, and gout in older adults. Arthritis Care Res (Hoboken), 67, 1730-1738.

[158] Chandratre, P., Roddy, E., Clarson, L., Richardson, J., Hider, S. L., \& Mallen, C. D. (2013) Health-related quality of life in gout: a systematic review. Rheumatology, 52, 2031-2040.

[159] Lee, Y-Y., Kuo, L-N., Chen, J-H., Lin, Y-C., Chen, L-F., \& Ko, Y. (2019) Prescribing patterns and healthcare costs of gout. Curr Med Res Opin, 35, 1051-1058.

[160] The Council for Science and Technology, Ministry of Education, Culture, Sports, Science and Technology in Japan. (2020) Standard tables of food composition in Japan -2020(Eighth Revised Edition), Report of the Subdivision Resources [Internet]. Available from: https://www.mext.go.jp/content/20201225-mxt_kagsei-mext 01110_011.pdf.

[161] U.S. Department of Health \& Human Services. National Institutes of Health. Office of Dietary Supplements. Dietary Supplement Fact Sheets [Internet]. Available from: Dietary Supplement Fact Sheets (nih.gov).

[162] Krishnamurthy, V. M. R., Wei, G., Baird, B. C., Murtaugh, M., Chonchol, M. B., Raphael, K. L., Greene, T., \& Beddhu, S. (2012) High dietary fiber intake associated with decreased inflammation and all-cause mortality in patients with chronic kidney disease. Kidney Int, 81, 300-306.

[163] Yahfoufi, N., Alsadi, N., Jambi, M., \& Matar, C. (2018) The immunomodulatory and anti-inflammatory role of polyphenols. Nutrients, 10, 1618. 